\footnotetext{
特集 高輸者医療を

特集 めぐる諸問題

順天堂医学 37 (1)

P. $15 \sim 25(1991)$
}

\section{高齢者医療における栄養・食事管理 ${ }^{* *}$}

Nutritional and dietary care in aged patients

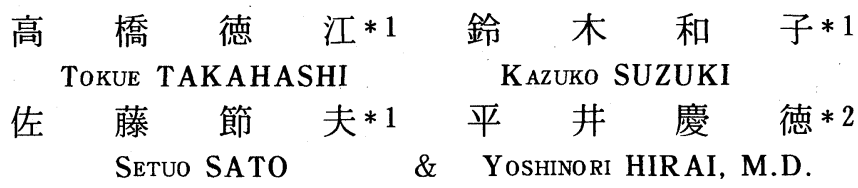

健やかに長寿を保つためには，栄養・食事管理が極めて重要である．ましてや，何らかの病 態を有する高歯者の栄養管理は，医療の一因子として重要な意義をもっている．そてで高齢者 の医療にあたっては，基本となる栄養所要量を把握し，栄養のアンバランスを可及的に防いだ 栄養管理をする必要がある。

1989年のわが国の国民栄養調査では，高齢者の食事に特に不足している栄養素はカルシウム であり，過㮃摂取が問題となるのは，エネルギー・脂肪・塩分との報告があった。てれらの栄 養条件を考えても, 骨粗鬆症や骨折, 動脈硬化の唐突な原因となり, ボケ・脳卒中による運動 機能の低下へとつながって行く．いわんや入院加療を必要とする高齢者では，それら以外の因 子についても十分な配慮をする必要があるはずである.

そこで本稿では, 高齢者栄養の特徵, 高齢者にみられるその他の特殊性, 高齢者栄養の実際 の 3 点について論述した。

索引用 語：高齢者医療，栄養管理，食事

Key words : geriatrics, nutritinal care, diet

医療の現場において栄養管理が果たしつつある 役割は重大である。乙れは最近 20 年間に，医療の あらゆる領域の治療成績を経静脈的，あるいは経 腸的な栄養管理が画期的に向上させたことからも 理解することができる. このような栄養管理の重 要性は, 乳幼児と高歯者を対象とした医療の場合

*1 順天堂大学医学部附属順天堂医院栄養部

* 2 順天堂大学医学部外科学 (小児外科) 助教授

* 1 Dietetic Division, Juntendo University Hospital, Tokyo, Japan

* 2 Dept. of Pediatric Surgery, Juntendo University School of Medicine, Tokyo, Japan

** 第255回順天堂医学会学術集会 [Nov. 17, 1990 開催 [Dec. 13, 1990 原稿受領〕
に特に強調されている。

そこで本稿では，乙の高齢者の栄養・食事管理 の特殊性, 問題点について述べてみたい.

\section{高齢者栄養の特徵}

1. 代謝面より

総ての消化酵素の分泌量は, 60 歳頃からいちじ るしく低下すると言われている.

図- 1 は唾液アミラーゼ量の年齢変化を示した ものである．60歳以後に明らかな低下が見られ， 炭水化物に対する消化能力の低下が示唆される.

図- 2 は胃液の主な成分のうち，たんぱく質分解 


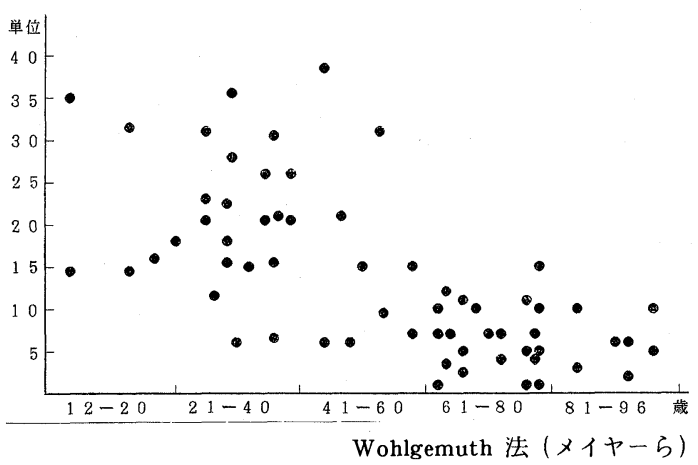

図-1 唾液ア之ラーゼ (プチアリン) 量の年齢変化

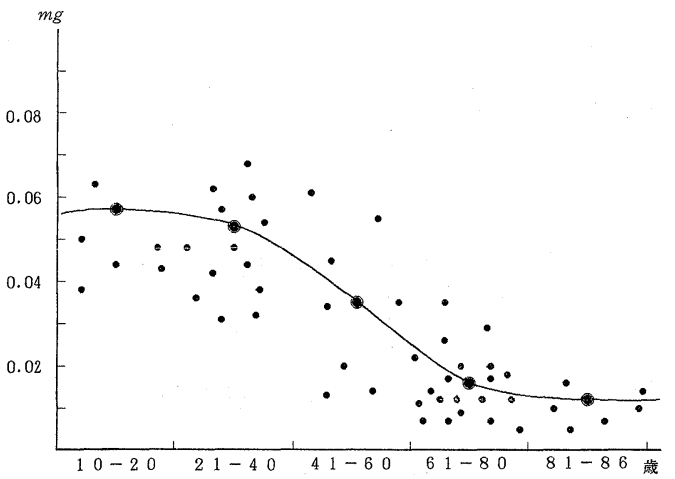

縦軸は試験管内消化でペプシンの作用により遊離するチロシン の量を示す

図- 2 ペプシン分泌量の年齢変化

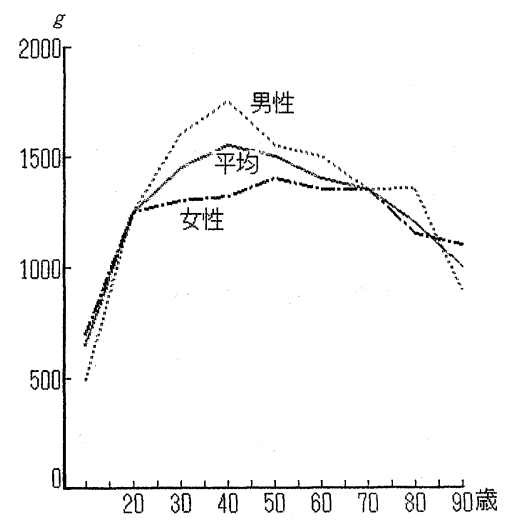

(ビレクら )

図- 3 肝臓重量の年齢による変化

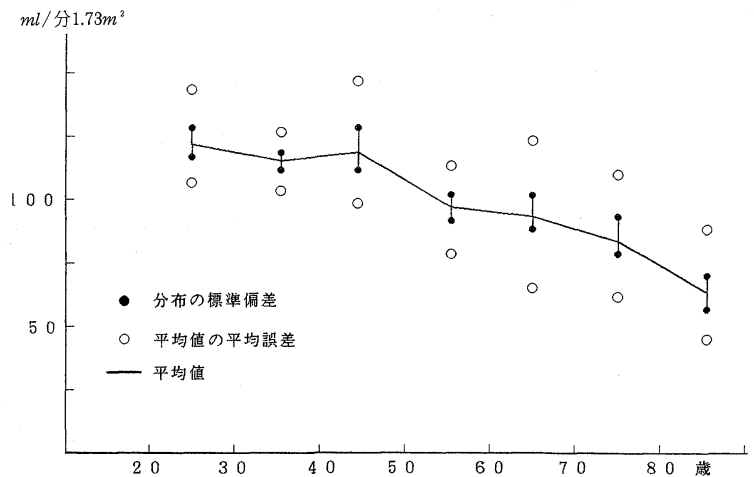

図- 4 腎クリアランスの年齢変化

醉素であるペプシンの分泌量の年齢変化である. 唾液アミラーゼと同様に加齢とともに低下を示し, 60歳代から著明に低值となる．従って，たんぱく 質の消化能力も衰えると考えられ，たんぱく質食 品に対する嗜好が低下する原因となるととが推測 できる.

肝臓は生体物質代謝の中心臓器であり, 多種多 様な機能を営んでいる. この機能も加歯とともに 低下することが容易に考えられるが，乙れを肝の 重量の加齢変化の面から示したのが図- 3 である. 女性では20歳から70歳までは大差なく，それ以後 ゆるやかに低下傾向を示す。乙れに対し男性は, 40歳代を頂点としてその後急激に低下する．乙の ような肝臓重量の減少は肝細胞の縮小, あるいは 肝細胞数の減少に起因するものと判断され, 肝臓 の機能的低下の傾向が推測できる.

図- 4 は, 生体の恒常性維持に重要な役割を果た している腎臓の加歯変化を腎クリアランスの変化 から捉えたものである. 両性とも40歳を過ぎる頃 から, 腎クリアランスは急に低下傾向を示し, 80 歳を過ざるとその機能は健康成人のそれの $50 \%$ 以 下にまで低下するとされている。このようなクリ アランスの低下した腎において, その機能の低下 の割合を最小限に食い止めるためには, 特に水分 摂取量と塩分の過剰摂取に留意する必要があると 考えられる.

以上のような加歯䎲伴う生体代謝機能の低下は, 
表- 1 高齢者と健康成人の栄養所要量の比較

\begin{tabular}{|c|c|c|c|c|c|c|c|c|c|c|c|c|c|c|c|c|c|c|c|}
\hline \multirow{2}{*}{$\begin{array}{l}\text { 年 齢 } \\
\text { (歳) }\end{array}$} & \multicolumn{2}{|c|}{$\begin{array}{c}\text { エネルギー } \\
(\mathrm{k} c a l)\end{array}$} & \multicolumn{2}{|c|}{$\begin{array}{r}\text { タンパク質 } \\
(\mathrm{g})\end{array}$} & \multirow{2}{*}{$\begin{array}{c}\text { 脂肪 } \\
\text { エネルギー } \\
\text { 比率 (\%) }\end{array}$} & \multicolumn{2}{|c|}{$\begin{array}{r}\text { カルシウム } \\
(\mathrm{g})\end{array}$} & \multicolumn{2}{|c|}{$\begin{array}{l}\text { 鉄 } \\
(m g)\end{array}$} & \multicolumn{2}{|c|}{$\begin{array}{r}\text { ビタミンA } \\
\text { (IU) }\end{array}$} & \multicolumn{2}{|c|}{$\begin{array}{r}\text { ビタミン Bl } \\
(m g)\end{array}$} & \multicolumn{2}{|c|}{$\begin{array}{c}\text { ビタミン } \begin{array}{c}\text { B } 2 \\
(m g)\end{array} \\
\end{array}$} & \multicolumn{2}{|c|}{$\begin{array}{r}\text { ナイアシン } \\
(m g)\end{array}$} & \multirow{2}{*}{$\begin{array}{r}\text { ビタミンC } \\
(m g)\end{array}$} & \multirow{2}{*}{$\begin{array}{r}\text { ビタミンD } \\
\text { (IU) }\end{array}$} \\
\hline & 男 & & 男 & 女 & & 男 & 女 & & 女 & 男 & 女 & 男 & tr & 男 & 女 & 男 & & & \\
\hline & & & 65 & 55 & $20 \sim 25$ & 6 & 0. & 0 & 10 & 2,000 & & 0.7 & & 1.0 & & 12 & & 50 & 100 \\
\hline$\sim 29$ & 250 & 1,800 & 70 & 60 & $20 \sim 25$ & 0.6 & 0.6 & 10 & 12 & 2,000 & 1,800 & 0.9 & 0.7 & 1.2 & 1.0 & 15 & 12 & 30 & 100 \\
\hline
\end{tabular}

高歯者の栄養, あるいは食事を考えるうえにも常 に念頭におかなければならない。

\section{2. 栄養面より}

健康の保持・疾病予防のためには, 基本となる 栄養所要量の認識が必要である. わが国の厚生省 から示された栄養所要量の年齢区分は, 従来 20 歳 以上の者については10歳きざみで示されていたが, 高齢社会の進行に,より適切な対応ができるよう, 第 4 次改定では60歳代・70歳代については 5 歳き ざみで示されている.

表- 1 は, 70 歳代前半の高齢者と 20 歳代の健康成 人の栄養所要量を比較したものである. 高齢者で は, 基礎代謝・生活活動指数の低下によりエネル ギ一所要量がいちじるしく低くなっているが，た んぱく質の比率や脂肪エネルギー比率, ビタミン・ ミネラル量にはほとんど差違がない。つまりエネ ルギ一量のみを減らし, 他の栄養量は健康成人と 同じ比率でとることが望ましいのである.

3 . 心理面より

NHK の世論調査によれば, 生活の充実度の評 価をレジャ一・娛楽, 子どもの教育, 住まい, 食 べものなどの面から行い，年齢別に表現すると 20 歳代前半ではレジャーや娛楽に，30歳代より50歳 代までは住まいや子どもの教育にウエイトがおか れている.しかし60歳代を過ぎる頃から，乙れら のような対象に関する楽しみは少しづつ低下し， 食べものを生活充実の方向とする比率のみが増加 傾向を示すとされている. これは高齢者にとって は，食べるという楽しみが積極的に生きることへ つながるための, 大切な心理行動であるととを示 していると考えられる.

\section{高齢者にみられるその他の特殊性}

1. 咀しゃく力の低下

図- 5 は年齢と亦失歯数の関係を示したもので ある. 65歳以上では喪失歯数は 20 本以上となり, 残っている歯は10本以下となってしまう. 従って, どうしてもある程度柔らかい食物を好むてとにな る. これは食事が糖質のみに偏る危険があるとと を示しており，他の栄養素の不足やエネルギーの 過唾摂取の原因ともなる. また，食物線維も不足 となるため十分注意が必要である.

すでに欧米では高齢者を中心にして低線維食に よる便量の減少が問題とされ, 過敏大腸や腸䡯室 病が,ささらには大腸癌の発生との関連が指摘され ている.

たとえば米国では, 腸憩室病発生率が1940年か ら1980年にかけて急激に増加し, 現在では $70 \%$ 近 くの人か腸墛室病を有している．最近わが国でも， 腸馣室病は増加傾向にあると言われており，今後 米国型食生活を追随するに従い, 食物線維摄取量 が低下していったなら, 腸輴室病の発生率が急増 することは容易に推測できる.

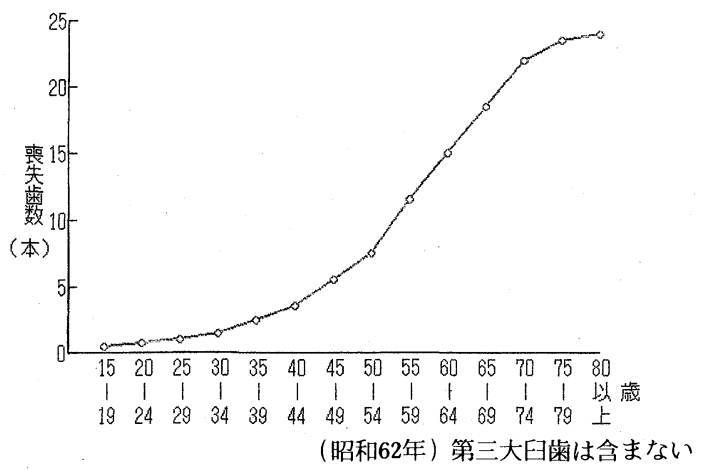

図- 5 䨤失歯数の状況 


\section{2. 嗜好の変化}

舌の表面には知覚神経の未端が広く分布してお り, 中でも味覚にたずさわる小器官として味蕾が ある. 表- 2 は舌の 1 有郭乳頭中の味蕾の数を年齢 別に示したものである。０歳より70歳までは大差 はみられないが，74歳を過ぎるとそれまでの $1 / 3$ 以下にまで急激に減少する。乙れは味覚感度が低 下する原因と考えられる.

てのような形態的退行は，味覚能にどのような 変化を与えるのであろうか. 図- 6 は味覚の年齢に よる変化を示したものである.酸・甘・塩・苦の 4 種の味覚感受性の調査によると, 60歳からいち じるしく閾值が上昇して感度低下をきたす．高齢 者の栄養・食事を考光る場合, 味付けが若年者向 きとは同じになりえない理由がここにある，特に 塩味の低下は塩分の過利摂取の原因となり, 高血 圧発生にプラスの因子となると考えられる.

味の好みを男女年齢別に調查した結果によると， いわゆる『濃い味—薄味』では男女とも高齢に なるに従い薄味を好むようになる。しかし，特に

表- 2 舌の味蕾数 $/ 1$ 有郭乳頭

\begin{tabular}{l|l} 
年 $\quad$ 齢 & 数 \\
\hline $0 \sim 11$ 力月 & 241 \\
$1 \sim 3$ 歳 & 242 \\
$4 \sim 20$ 歳 & 252 \\
$30 \sim 45$ 歳 & 200 \\
$50 \sim 70$ 歳 & 214 \\
$74 \sim 85$ 歳 & 88 \\
\hline
\end{tabular}

(Arey et al., 1935)

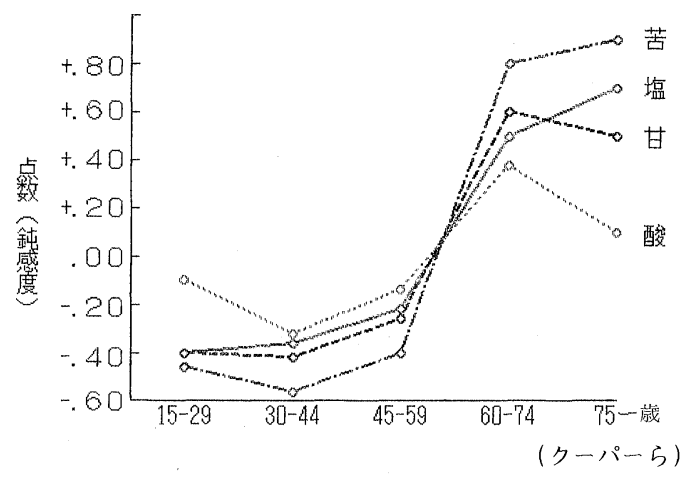

図-6味覚の年齢による変化
塩味に対しての味覚が低下している高齢者では, 自分でも気づかずに塩辛い味の食事をとりがちな ことは日常もしばしば経験することである.

『甘い一辛い』の対比では, 男性の場合60歳を 過ぎる頃から急に辛い味が苦手となり，甘い味を 好むようになる，女性では 30 歳を過ぎる頃から， 辛い味より甘い味を好む者が徐々に増加し, 男性 同様60歳を過ざる頃から甘い味を好む者が圧倒的 に多くなる.乙こで問題となるのは, 甘い味＝砂 糖の取り過ぎであり, 砂糖の過㮃摂取はエネルギー 過剰摂取へとつながり, 肥満・動脈硬化の原因と もなる。

『油ってい—さっぱり』の対比では, 男女とも 日本人は一般的にさっぱり好きが多く, しかもそ の比率は加齢とともにますます急增し, 高齢者で はきわめて高率となる. しかし, 栄養所要量より も判断できるように，ててで脂肪を極端に減らす のは望ましいことではない. 質の良い脂肪をある 一定量摂取するととが必要である.

\section{3．食べ物に対する意識}

現在55歳以上の日本人は, 第 2 次大戦中および

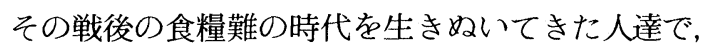
食べ物に対する有難たさの感覚が強く, 食べ残す ともったいないと思う人が多いのが特徵である. 特に60〜70歳代を過ぎると 9 割近くが「食べ残す ともったいないと感じている.

食べ物を大切にすること, それ自身は大変意義 のあることであるが最近の豊かな食生活の中で, いわゆるで馳走を残さず食べてしまえばどうして も過郵栄養につながる. 健康上摂食が必要な人と か, ある種の食品を控えなければならない人とっ ては, むしろ努めて食べ残すことが求められる時 代になっている。

\section{高齢者栄養の実際}

\section{1. 栄養所要量と現状の比較}

図-7は，昨年のわが国の70歳代高齢者の 1 日の 栄養摂取量と所要量 (RDA) とを対比したもの である。 


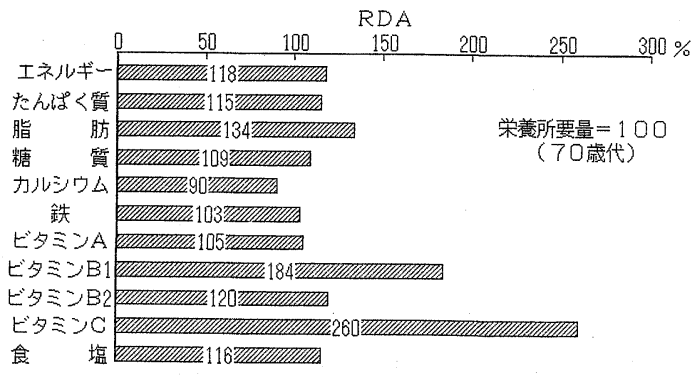

図- 7 わが国の70歳代高齢者の栄養所要量と摂取量の 比較（1989年度）

表- 3 骨粗鬆症の頻度 (腰椎のX線検査)

\begin{tabular}{c|r|r} 
年 齢 & \multicolumn{1}{c}{ 頻 } & \multicolumn{1}{c}{ 度 } \\
\hline (歳) & 男 & 女 \\
\hline $41 \sim 50$ & 1 & 10 \\
$51 \sim 60$ & 11 & 28 \\
$61 \sim 70$ & 6 & 62 \\
$71 \sim 80$ & 23 & 70 \\
$81 \sim$ & 30 & 100 \\
\hline
\end{tabular}

(慈大整形外科)

示された各栄養素の中ではカルシウム摂取量の みか所要量より少なく, その他の栄養素は全て所 要量より過剩である.つまり栄養所要量を基準に 高齢者の平均的摂取量を考えた場合, 低栄養が問 題となるのは, 掲示された栄養素中ではカルシウ ムのみであり, 他は総て過剰摂取で, なかでも特 に注意が必要となるのはエネルギー・たんぱく質・ 脂肪・塩分であると言える.

2. 低摂取量か関連する疾病と食事方針

1 ）カルシウムと骨粗鬆症

カルシウム代謝と骨粗鬆症との関連は大変に密 接である. 高齢者では骨を形造っている無機成分 であるカルシウムと, 有機成分であるコラーゲン の密度が歩調を揃えて少なくなるため, 骨がもろ くなり骨粗鬆症が発症する. 表- 3 は, 東京慈恵会 医科大学整形外科の行った腰椎のX線検查による 骨粗影症の頻度である. 発生は当然, 性・年齢に 関係があり, 女性に多く中年期以降 60 歳を過ぎる と急速に増加する．81歳以上の女性では $100 \%$,
男性は女性より10年遅れて出現, 徐々に増加し, 81 歳以上で $30 \%$ のにみられる. わが国の骨粗㑥 症患者は現在 500 万人と推定される. この数の大 きさは, 潜在的に糖尿病を有している患者 250 万 人の倍に当たることからもその重要性が理解でき る.

<骨粗鬆症の対策 $>$

(1) 1 日600mg量のカルシウム摄取

牛乳や乳製品のカルシウムは消化管で比較的よ く吸収されるが, 野菜のカルシウムは線維やフィ チン酸・蓚酸の妨害によって吸収率が低くなる. 摂取方法としては 1 日分の $1 / 2 \sim 2 / 3$ を牛乳・ 乳製品で, 残りを小魚・大豆・でま・海藻・緑黄 色野菜などの食品から摂取するのが理想的である. 骨粗鬆症が完成してからあわててカルシウムを補 充してもあまり効果がなく, 常日頃からの摂取量 に十分注意することが肝要である。

(2)良質なたんぱく質を十分にとる

カルシウムの骨への定着のため良質なたんぽく 質を十分とることも大切である. 牛乳および乳製 品・卵・豆腐・魚・脂肪の少ない肉類などが栄養 価が高く消化もよく理想的である．ただし，たん ぱく質摂取量が過剰になると尿中のカルシウム排 泄量が増加するため, 摂取量は所要量を満たす程 度が望ましい。

(3)ビタミンDを多く含む食品の摂取

ビタミンDはカルシウムの腸管吸収を促進し, カルシウムの骨からの溶出ならびに骨への沈着を 調整している. 表皮に高濃度に存在している 7 -デ ヒドロコレステロールは, 日光照射によりビタミ ンD $\mathrm{D}_{3}$ 転換するが，ほとんど屋外にでることがな いような高踰者ではビタミンDの食事からの補給 は不可欠である. 1 日当たり100IUのビタミンDの 摂取がカルシウムの腸管吸収を円滑に行い，骨に おける化骨化を正常にするために適当とされてい る.ビタミンDは，いわし・かつおなどの魚類に 多く含まれている.

(4)リンの過剩摂取に注意

リンはカルシウム代謝と関係が深く, 摂取量は $1,300 \mathrm{mg}$ 前後であるととが望ましいとされている. 
現時点のわが国でのリンの摂取量には問題ないが， 摂取量が2000mgを越えるとカルシウム出納の負 平衡, 副甲状腺機能の六進をきたすことが指摘さ れている. 近年, 各種りン酸塩が食品添加物とし て加工食品に広く用いられる関係で, リンの過剰 摂取に注意が必要とされている.

(5)塩分の節減

日本人の食事は食塩を比較的多く含むととが特 色である.ナトリウムはカルシウムの尿中への排 泄を促進させ, カルシウムの利用率を低下させる. たとえば同量のカルシウムを摂取しても，ナトリ ウムを過剰に摂取すれば，それだけカルシウムの 利用が減少することになるため, カルシウムの摂 取量を増加させなければ同じ効果を得ることはで きない。

2 ）マグネシウムと虚血性心疾患

最近, マグネシウム摄取量と虚血性心疾患と の関係が問題となっている.図-8は日米両国の 食事中のカルシウム・マグネシウム比の年次推 移である．高齢者の間にカルシウム欠乏による 骨粗鬆症患者が急増し, この状態を改善しよう とカルシウム摂取量を増やすてとが推奨されて いるが, マグネシウムは食生活の欧米化に伴い 進んで減少する傾向にあり, カルシウム・マグ ネシウムの比率が次第に上昇して, 米国に近づ いてきていると言われている.カルシウム・マ グネシウムの比が高くなると, 虚血性心疾患な どの循環器疾患が多くなると強く指摘されてお

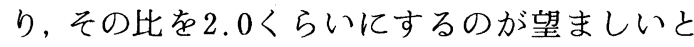
されている. 従って, カルシウム所要量は 1 日 当たり $600 \mathrm{mg}$ であるから, マグネシウム所要量 は $300 \mathrm{mg}$ 前後に設定すればよいと考えられてい る。

マグネシウムがなぜ，虚血性心疾患などの循環 器疾患の発生防止に必要なのかはまだはっきり分 かっていないが, 脳動脈や心臓冠状動脈の血管細 胞内に過檋なカルシウムが取り込まれると血管け いれんが起こり，脳卒中や心筋梗塞の原因になる のではないかと考えられている.

現在，わが国の食品成分表にはマグネシウムの

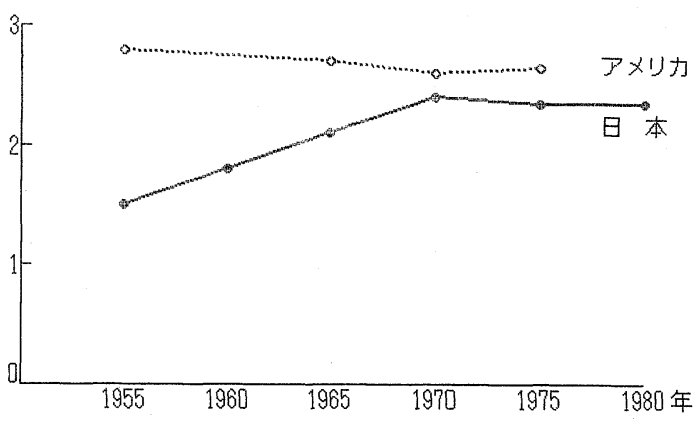

図-8 日米両国の食事中カルシウム・マグネシウム比 の年次推移

値は示されておらず, 所要量も決められていない. 今後の検討が望まれる.マグネシウムの豊富な食 品は数少なく, 玄米・麦・アーモンドなどのナッ ツ類・海藻・抹茶・インスタントコーヒーなどが 補給源となる.

3 ）食物線維と種々の成人病

マグネシウムと同様に所要量と摂取量の対比で は触れていないが, 食物線維不足と種々の成人病 との関連は大変に密接である.

表- 4 は食物線維の摂取不足と種々の成人病と の関係を示したものである. 栄養過㮃吸収が原因 となる成人病では, コレステロール・中性脂肪の 過鄱吸収により, 動脈硬化・胆石が著起されると 言われている. 炭水化物過利の場合は糖尿病が, 炭水化物・脂肪では肥満が生じやすくなる.また, 線維の捸取不足によって起こった腸内細菌叢の変 化が原因となり, 発ガン物質が産生され腸ポリー プや大腸ガンの原因となると言われている。ささ に䔬便の停滞による腹圧上昇では静脈瘤などが, 同じく霬便の停滞による腸内圧上昇では腸㕰室病 や虫垂炎などが発生するとされている.

食物線維には血清脂質を低下させ, 糞便の腸管 通過時間を短縮させるだけでなく，耐糖能異常を 改善する作用なども有しているてとが知られてき ている，そてで食物線維を健康のために，日常の 食事の一部として習慣的に，しかも多めに摄取す ることが大切となる.

高齢者では, 経腸栄養剤によるチューブ栄養を 
表- 4 食物線維不足による成人病

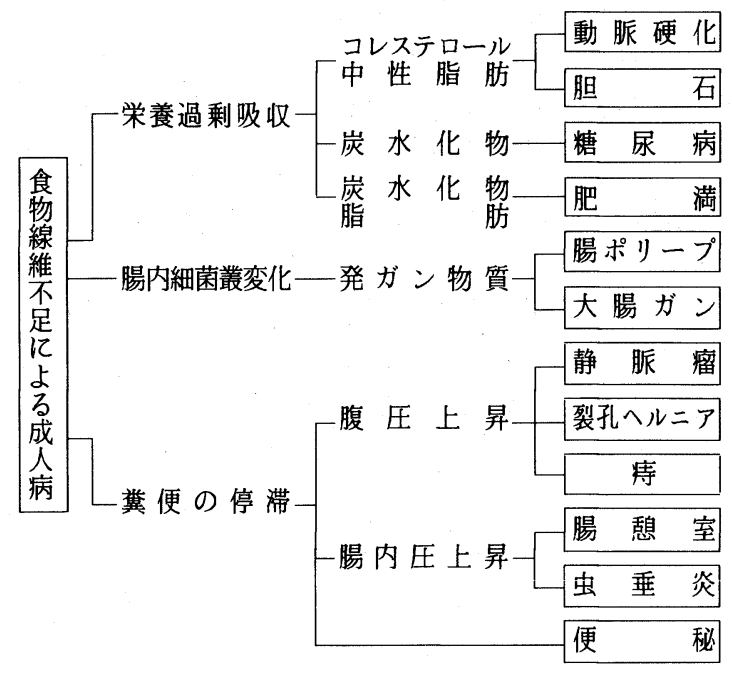

長期に渡って行う例が少なくない。乙れに用いら れるいわゆる高カロリ一経腸栄養剤の特徵は, 残 椬すなわち線維がほとんど含まれていないことで ある. この特徵は短期間, すなわち手術前後のよ うな急性期にはそれなりに大きな長所ではあるが, 長期に渡る場合には, 食物線維不足が原因となる 疾病に注意が必要となる．従って，長期投与患者 では, 人参末・アップルファイバーなどの食物線 維を添加することが望まれる。しかし，乙れらの 食物線維は現在社会保険の適用はされておらず, 食品として扱われているため留意しなければなら ない。

3. 過㮃摂取が関連する疾病と食事方針

1) エネルギーと肥満

原則的には老年期に入れば齢とともに摂取エネ ルギーを減らしていくのが自然であるが, 食習慣 は老年期に入ってもさほど変わらない人が多いの が実状である．そのため摂取エネルギーと消費エ ネルギーのアンバランスが生じる可能性が大きく, 初老期から老年期にかけて肥満を生じる原因とな る.

皮下脂肪厚からみた肥満者の割合は男女とも50 歳代に最も多く，女性で 4 人に 1 人，男性で 7 人 に1人となっている.
肥満とは厳密には体内の脂肪の割合が増加する ことである. 高龄者の身体構成は代謝組織量が減 じ，体重中の脂肪の割合が増加している傾向にあ るため, 中年を過ぎて体重が増加する場合にはほ とんどが脂肪の増加である.

肥満は心臟に負担をかけ，また中年以後に多い 糖尿病発症の誘因となる.さらに高歯者では重い 体重をささえるために膝の故障を起ししやすく， 一方腹部に脂肪が多量に沈着すると横隔膜を持ち 上げ, 二次的にも心臓や肺の機能を障害すること になりやすい. また, 心臓の筋肉や肝臓の細胞の 間にも沈着して, これらの臓器の機能を阻害する. 従って, 高齢者における体重の増加は健康を保つ うえに，どうしても避けなければならない。

$<$ 肥満対策>

\section{(1)摂取エネルギーの制限}

自分の標準体重を知り適正なエネルギー量を守 る. 但し高歯者においては, 潜在的疾病を有して いたり，また免疫能の低下のため疾病に罹患する ことが多く, 体力の減弱を招く急激な体重減少を はかることは好ましいことではない. 1 力月に 1

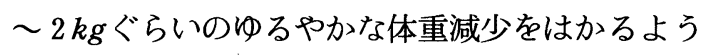
に指導することが望まれる. 標準体重に対して 1 $k g$ 当たり $25 \mathrm{k} c a l$ ぐらいの計算で処方するとよいと 思われる.

(2)適正なたんぱく質・脂質・糖質・ビタミン・ ミネラルの確保

健康的にやせることが絶対条件であるため, 必 要な栄養素を過不足なく摂ることは不可欠である.

(3)規則正しい食事

食事回数を減らした結果, 食事から食事までの 時間が長くなり, この空白を埋めるために身体は 脂肪を貯え, 非常の場合に備えようとする.つま り， ゆっくりよく嚙んで三食規則正しく食べるて とが, 瘦せることへの第一歩である.

(4)食物線維の摂取

(5)塩分を節減

2 ）脂肪之動脈硬化

心臟や脳の血管系の疾患の発生には多くの場合, 動脈硬化が関与しており, 高齢者では動脈硬化が 


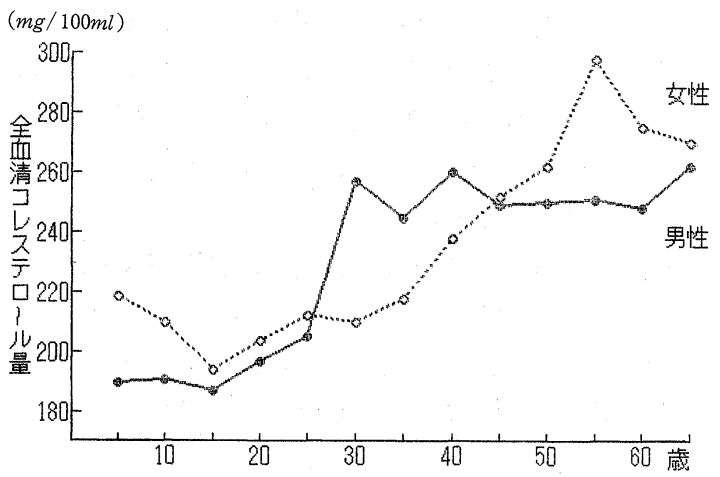

図-9 血中コレステロールレベルの年齢による変化

原因と考えられる脳梗塞は依然として増加傾向を 示している.

図-9は血中のコレステロールレベルの加齢に よる変化を示している. 血中のコレステロール量 は, 生理的にも加齢とともに増加することが分かっ ている. 特に女性では50歳を過ぎる頃から急激に 高くなる. 血管壁にコレステロールを多く含む物 質が沈着して起しってくる䉼状硬化症は, 狭心症 発作を起ししたり心筋梗塞の原因となる.

高齢者の多くは筋力その他, 運動量などの低下 から超低比重りポ蛋白（VLDL）の上昇を招きや すくなる. また, 糖質が過剰となりやすいため中 性脂肪の増加と高比重りポ蛋白（HDL）の低下が 生じやすくなる。一般に動脈硬化病変を生ずる高 脂血症は, コレステロールの上昇をともない LD L や IDL の増加する型とされている. HDL は 動脈硬化に対する防御因子とみなされており, 高 HDL 血症あるいは高 HDL コレステロール血症 患者では, 虚血性心疾患の発生は少なく平均寿命 も長いため, 長寿症候群と言われている. 通常, 中性脂肪は血管病変に対する影響は少ないとみな されており, むしろ脂肪肝・胆石・膵炎の頻度が 高く, 肥満・糖尿との関係が深いと言われている. しかし, 高中性脂肪血症にはしばしば低 HDL 血 症をともなう例が多いため, 動脈硬化の危険因子 と考えられている。
＜動脈硬化対策>

(1)摂取エネルギーの制限

摂取エネルギーは高齢者の活動能力に応じて調 整すべきであるとされており, 一般に標準体重当 たり25〜30kcalが適当とされている.あくまでも 過食は慎しみ, 高中性脂肪血症を誘導しないよう にする.

(2)動物性脂肪を控える

多価不飽和脂肪酸と飽和脂肪酸の比を $1 \sim 2$ と し, この際多価不飽和脂肪酸としてはリノール酸・ アラキドン酸，あるいは魚類，特にいわしに多く 含まれるエイコサペンタエン酸・ドコサヘキサエ ン酸の含有量の多い食物を摂るようにする。一方, てれら多価不飽和脂肪酸は分解を受けやすいので, 光・熱などに注意し，ビタミンEを十分投与して 過酸化を防止する必要がある.

最近, ビタミンEの栄養状態が良い地域は, 悪 い地域に比べて虚血性心疾患や癌の死亡率が有意 に低く,また脳卒中の発生率が少ないことなどが 報告されている．乙のように老化と成人病におけ るビタミンEの役割は大変重要視されている. 高 齢者のビタミン $\mathrm{E}$ 目標摂取量は, 健康成人の場合 と同様に 1 日 $8 \mathrm{mg}$ とされており, 植物油や緑黄色 野菜, 豆類, 牛・豚の肝臓, 卵黄などから摂取す ることになる.

(3)食品からのコレステロール摂取量は 1 日 300 $m g$ 程度

高齢者では一般にコレステロール摂取量は減少 するととが多いので, この点では問題は少ないと 思われる.

(4)菓子類やアルコールなどの嗜好品, 果物の過 量摂取に注意.

(5)食物線維の摂取

食物線維の摂取はコレステロール代謝を通して 動脈硬化に有効である. 粗線維量で $4 \sim 5 g /$ 日, 総線維量で15～25g／日ぐらい摂取することが望 ましいとされている，便秘などを訴える場合には なおさらである。

(6)塩分の節減 


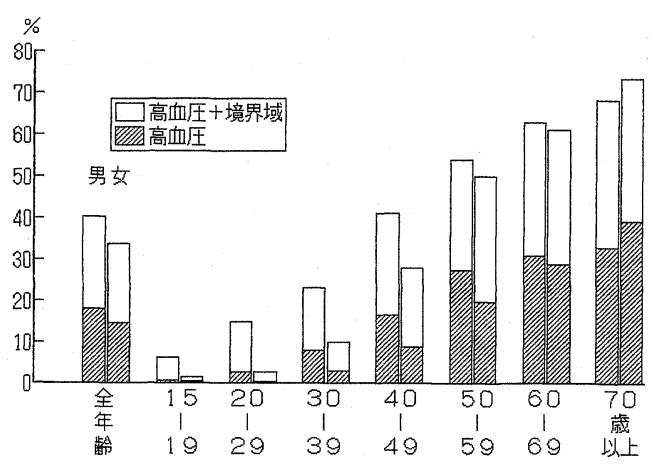

図-10 血圧の状況（性・年歯階級別）

3 ）塩分（食塩）と高血圧

循環血液量の調整に大きな影響を及ぼすのが食を 塩の摂取量と腎の排泄機能である. 前述したよう に高齢者では塩味に対する閾值が高く，また腎機 能も低下するため, 高血圧の頻度が高くなる.

図-10は血圧の測定結果から, 性・年齢別に高血 圧および境界域高血圧者の割合を示している，男 女ともに加齢とともに増加しており，特に女性は 若年層に比較し急な増加を示している，境界域を 含めると70歳以上では約 $70 \%$ が高血圧である.

<高血圧対策 $>$

(1)塩分（食塩）の制限

食事方針としては，塩分（食塩）の制限がもっ とも大切である. 1 日に食塩 $5 \sim 8 g$ とし, 食塩含 有量の多い食品を覚えてもらったり食塩制限が守 られるような調理法の工夫を指導する.

また，一品のみ塩味を重点的につけ，他は薄味 にするなどの工夫も必要である.

(2)摂取エネルギーの制限

適正なエネルギー摂取量とし，肥満を是正する.

(3)適正なたんぱく質・脂質・糖質・ビタミン・ ミネラルの確保.

(4)カリウムの十分な補給

食事中のカリウム量は不足しないようにするが, 腎不全例では高カリウム食は好ましくない. 食事 中のカリウム／ナトリウムの比を可能な範囲で高 くすることが望ましい．

(5)食物線維の摂取
表- $5 \quad 70$ 歳の高齢者の摂取量

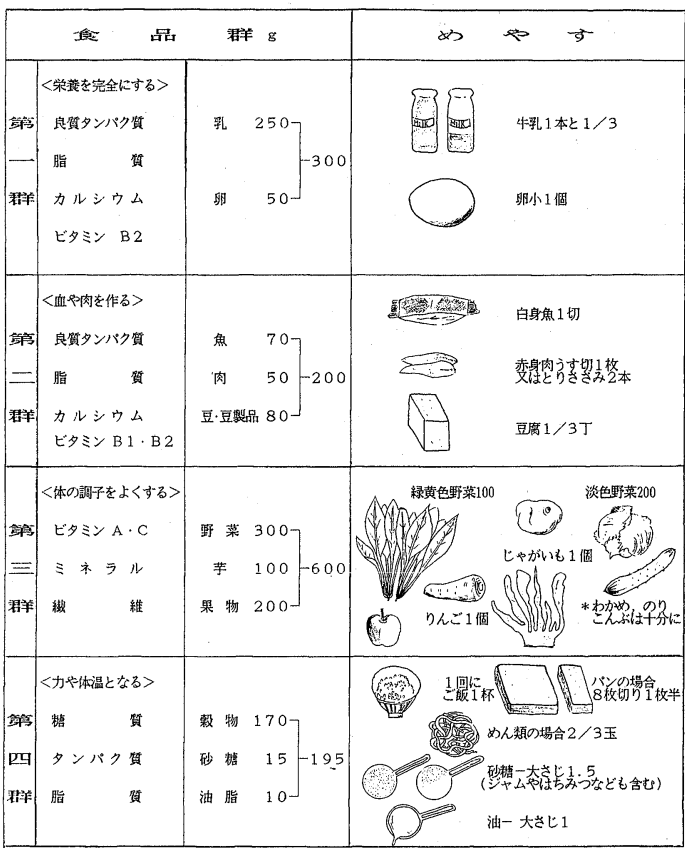

4 ）高齢者の 1 日の食品構成と献立例

(1) 1 日の食品構成

表- 5 は 4 つの食品群に基づいた70歳高㱓者の食 品構成である.

1 群は栄養を完全にする優秀な食品群で, 牛乳・ 卵が含まれる。 1 日に牛乳 1 と $1 / 3$ 本，乙れは ヨーグルトやチーズなどの乳製品に代替してもよ い. 卵は小 1 個がめやすである.

2 群の食品は良質なたんぱく質を多く含む魚・ 肉・豆製品で，1日に白身魚 1 切，とりささみ 2 本, 豆腐 $1 / 3$ 丁がめやす量となる.

3 群はビタミンやミネラル，線維を多く含む野 菜・芋・果物である.1日のめやすは緑黄色野菜 $100 \mathrm{~g}$, 淡色野菜 $200 \mathrm{~g}$, じゃがいも 1 個, りんご 1 個で, この他わかめ・のりなどの海藻類は十分に とるようにする。

4 群は主にエネルギー源となる穀物・砂糖・油 脂類である.ごはんは 1 回に 1 杯，砂糖は 1 日に 大さじ 1.5 杯, 油は植物油大さじ 1 杯がめやすで ある. 
表- 670 歳の高齢者の献立例

\begin{tabular}{|c|c|c|c|c|c|c|c|}
\hline & 献 立 名 & 食品名 & $\begin{array}{c}\text { 数 量 } \\
(g)\end{array}$ & $\begin{array}{l}\text { エネルギー } \\
(\mathrm{k} c a l)\end{array}$ & $\begin{array}{c}\text { たhぱく質 } \\
(g)\end{array}$ & $\begin{array}{c}\text { 脂 質 } \\
(g)\end{array}$ & $\begin{array}{c}\text { 糖 質 } \\
(g)\end{array}$ \\
\hline & ごは ん & ごは ん & 140 & 207 & 3.6 & 0.7 & 44.4 \\
\hline & 味 噌 汁 & 味噌 & 10 & 19 & 1.3 & 0.6 & 1.9 \\
\hline & & かぶ・葉 & 30 & 6 & 0.4 & 0 & 0.9 \\
\hline \multirow[t]{4}{*}{ 朝 } & ポーチドエッグ & 卵 & 50 & 81 & 6.2 & 5.6 & 0.5 \\
\hline & & ブロッコリー & 30 & 13 & 1.8 & 0 & 2.0 \\
\hline & & プチトマト & 10 & 2 & 0.1 & 0 & 0.3 \\
\hline & ひじきの炒り煮 & なまり & 20 & 14 & 3.0 & 0.2 & 0 \\
\hline \multirow[t]{4}{*}{ 食 } & & ひ じき & 8 & - & 0.8 & 0.1 & 3.8 \\
\hline & & 人 参 & 10 & 3 & 0.1 & 0 & 0.6 \\
\hline & & 砂 糖 & 3 & 12 & 0 & 0 & 3.0 \\
\hline & & 油 & 3 & 28 & 0 & 3.0 & 0 \\
\hline & ヨーグルト & 11 & 100 & 76 & 3.5 & 0.1 & 15.5 \\
\hline & 惹込みうどん & う ど $h$ & 190 & 192 & 4.8 & 1.0 & 38.6 \\
\hline & & 砂 糖 & 3 & 12 & 0 & 0 & 3.0 \\
\hline & & ささみ & 30 & 32 & 7.1 & 0.2 & 0 \\
\hline & & ほうれん草 & 20 & 5 & 0.7 & 0 & 0.7 \\
\hline \multirow[t]{5}{*}{ 昼 } & & 人 参 & 20 & 6 & 0.2 & 0 & 1.2 \\
\hline & & 生しいたけ & 10 & - & 0.2 & 0 & 0.5 \\
\hline & & ね ぎ & 10 & 3 & 0.1 & 0 & 0.6 \\
\hline & 豆腐の田楽 & 木綿豆腐 & 80 & 62 & 5.4 & 4.0 & 0.6 \\
\hline & & 味噌 & 5 & 10 & 0.6 & 0.3 & 1.0 \\
\hline \multirow[t]{8}{*}{ 食 } & & 砂 糖 & 2 & 8 & 0 & 0 & 2.0 \\
\hline & & 木 の 芽 & 1枚 & - & - & - & - \\
\hline & 二 杯 酢 & 若 布 & 0.5 & - & 0.1 & 0 & 0.2 \\
\hline & & 胡瓜 & 50 & 6 & 0.5 & 0.1 & 0.8 \\
\hline & & 白 す干 & 5 & 9 & 1.9 & 0.1 & 0 \\
\hline & 果 物 & みかん & 100 & 44 & 0.8 & 0.1 & 10.9 \\
\hline & さつま芋と & さつま芋 & 80 & 98 & 1.0 & 0.2 & 23.0 \\
\hline & りんごの重ね惹 & リ んご & 50 & 25 & 0.1 & 0.1 & 6.6 \\
\hline \multirow[t]{2}{*}{ 間 } & & マーガリン & 5 & 38 & 0 & 4.1 & 0 \\
\hline & & 砂 糖 & 3 & 12 & 0 & 0 & 3.0 \\
\hline \multirow[t]{6}{*}{ 食 } & 抹茶ミルク & & 150 & 98 & 4.7 & 5.1 & 7.2 \\
\hline & & 糖 & 2 & 8 & 0 & 0 & 2.0 \\
\hline & & 抹 & 1 & - & 0.3 & 0.1 & 0.3 \\
\hline & しめじごはん & 茶 飯 & 140 & 207 & 3.6 & 0.7 & 44.4 \\
\hline & & しめじ & 20 & - & 0.4 & 0.1 & 0.7 \\
\hline & & さやえんどう & 3 & 1 & 0.1 & 0 & 0.2 \\
\hline \multirow[t]{7}{*}{ 夕 } & かき玉 汁 & 卵 & 10 & 16 & 1.2 & 1.1 & 0.1 \\
\hline & & かたくり粉 & 1 & 3 & 0 & 0 & 0.8 \\
\hline & 生 鮭 の & 生 鮭 & 70 & 84 & 10.4 & 4.2 & 0.1 \\
\hline & 野菜あんかけ & $も や し$ & 50 & 13 & 1.7 & 0.1 & 2.1 \\
\hline & & 人 参 & 10 & 3 & 0.1 & 0 & 0.2 \\
\hline & & ピーマン & 5 & 1 & 0 & 0 & 0.2 \\
\hline & & 油 & 2 & 18 & 0 & 2.0 & 0 \\
\hline & & かたくり粉 & 2 & 7 & 0 & 0 & 1.6 \\
\hline & いとこ煮 & 南瓜 & 80 & 58 & 1.4 & 0.2 & 14.0 \\
\hline & & 小 & 10 & 34 & 2.0 & 0.2 & 5.4 \\
\hline & & 砂 & 2 & 8 & 0 & 0 & 2.0 \\
\hline & 計 & & & 1579 & 70.2 & 34.3 & 246.9 \\
\hline
\end{tabular}

カルシウム $: 0.8 \mathrm{~g}$ 鉄 $: 13.4 \mathrm{mg}$

ビタミンA : 3762IU ビタミン $\mathrm{B}_{1}: 0.97 \mathrm{IU}$ ビタミン $\mathrm{B}_{2}: 1.5 \mathrm{mg}$ ビタミンC : $184 \mathrm{mg}$ ビタミンD : 121IU 粗線維 $: 5.7 \mathrm{mg}$
(2) 1 日の献立例

表- 6 に1 日の献立例を示した。

朝食は消化の良い温泉卵をメイン に，高齢者に不足がちなうネラルや， 食物線維に富むひじきの炒り煮を添 えた和風献立である.

昼食は高齢者に好まれる煮込みう ぞんに，豆腐のみそ田楽と酢の物を 組み合わせた。

おやつはさつま芋とりんでの重ね 煮に抹茶えルクである. 抹茶はビタ ミンCやマグネシウムに富む食品で, ほろ苦い日本的な香りがお年寄りに 好評である.

夕食には秋の味覚を織り込んだ, しめじではん・かき玉汁・生鮭の野 菜あんかけ・かぼちゃと小豆のいと て煮という献立である.

\section{5 ) 順天堂医院での現状}

高橉化社会の到来とともに，順天 堂医院でも高齢患者の割合が増加傾 向となってきた．そこで入院中の 65 歳以上の患者 122 名を対象に，実際の 食事の摂取量を調查した。 その結果 が図-11である，契食率は 6 日間を通 して $80 \%$ とおおむね良好である．前 述したように，高齢者にとって食事 は残された数少ない楽しみのひとつ である．食事内容から季節の移り変 わりを知ったり, 療養に対する態度 や気構えの変更が期待できるわけで ある. 従って, 急増する高歯患者の食 事にいかにきめ細かく対応していく かが，今後の大きな課題であると考 えている.

\section{おわりに}

高歯者の栄養・食事管理を考える うえで,まず基礎としてその特殊性 


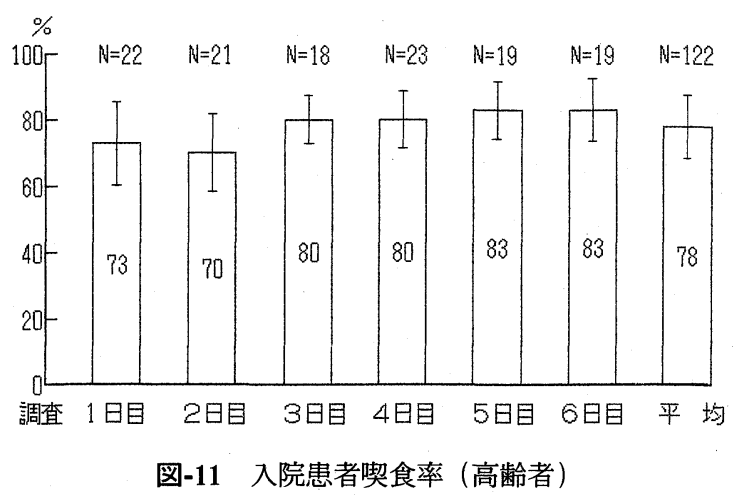

に対する理解が必要である，そうして低栄養を補 正し, 過唾摂取を是正して, 栄養所要量にみ合っ た量を, どのように摂取させるかが実際上の問題 となる。

そのためには, 高齢者の多種多様な生活歴・食 習慣などを十分把握し, 個々に適応した栄養指導 が重要である.

今後とも医師や看護婦との連携を密にしながら， 適切で快適な栄養・食事管理を進めて行くよう努 力したいと思っている.

\section{参考文 献}

1 ) 厚生省保健医療局健康增進栄養課：第 4 次改定 日本人の栄養所要量. 1989

2 ) 厚生省公衆衛生局：国民栄養の現状. 1989

3 ) 香川 綾監修：4 つの食品群の年齢別・性別・労 作強度別食品エネルギ一構成. 女子栄養大学出版部四 訂食品成分表, 1986

4 ) NHK 世論調査部編：日本人の食生活, 1985

5 ）糸川嘉則：生体微量金属の話. 自然の友社, 1987

6 ) 綾野雄幸：食物繊維はガン・成人病を予防する. 講談社, 1986

7 ) 田多井吉之介, 他 : 加齢の健康学. 大修館書店, 1984

8 ) 小池五郎：やさしい栄養学. 女子栄養大学出版部, 1976

9 ）柳沢幸江：年齢とおいしさ. 臨床栄養, 77(4) 391 $\sim 397: 1990$

10）熊原雄一, 他 : 老年者の病気と食事管理. 臨床栄 養, 66(3) $217 \sim 223,335 \sim 338,356 \sim 365: 1985$

\section{抄 録}

食塩摂取により生じた致死的高ナトリウム血症 : その症例報告と文献的考察

Fatal hypernatremia from exogenous salt intake : Report of a case and review of the literature Kevin G. Moder, Daniel

L. Hurley. Mayo Clin Proc 65 : 1587 1594, 1990

高ナトリウム血症は, その殆んどが水分の涸渴によ り, しばしば生じる一般的な電解質異常である。過剩 のナトリウム摄取记起因する高ナトリウム血症は少な く, 致死的な高ナトリウム血症が食塩の摂取化より単 独で生じるのは稀れである. 著者らは, うがい目的で 過飽和食塩水の摄取後, 急な発作と高ナトリウム血症 を来たした41歳の男性の症例について報告する.

症例は, カップ約 $1 / 3$ の食塩（およそ70-90g, Na として 1,200-1,500meq）を飲み尽くした. 患者の当 初の血清 $\mathrm{Na}$ 濃度は $209 \mathrm{meq} / l$ であった. 自由水供 給と, 徐々に高ナトリウム血症を補正するために，低 張輸夜療法が行われた。しかしながら, 患者は最初
の発作から回復せず，3 日後に死亡した。文献的には， 過度の食塩の摂取により高ナトリウム血症を呈した 10 人の成人と 20 人の小児についての報告がなされている. 治療の方法 (輸液あるいは腹膜透析), 用いた輸液の 種類, 及び高ナトリウム血症の修正率は, 生存に関係 していなかった. 患者の年齢と最初の血清 $\mathrm{Na}$ 濃度 が最も重要な予後の指標となっている. 即ち, 非常に 若い患者と高ナトリウム血症の程度の低い患者では, 他に比べて生存率が高かった. 加えて, 驚く程少量の 食塩でも重度の高ナトリウム血症を起てしており，吐 剤として食塩あるいは塩類を使用するてとの危険性を 示唆している. 